\title{
CFMS Tyrosine Kinase Inhibitor ARRY-382
}

National Cancer Institute

\section{Source}

National Cancer Institute. CFMS Tyrosine Kinase Inhibitor ARRY-382. NCI Thesaurus.

Code C96227.

A small molecule and orally available inhibitor of colony-stimulating factor-1 receptor (CSF1R; CFMS) with potential antineoplastic activity. CFMS tyrosine kinase inhibitor ARRY382 binds to and inhibits the activity of cFMS. By preventing colony-stimulating factor-1 (CSF-1)-cFMS signaling, this agent may inhibit tumor cell proliferation in cFMSoverexpressing tumor cells. cFMS, a tyrosine kinase receptor, is overexpressed in certain tumor cell types and plays an essential role in macrophage differentiation and regulation of cell proliferation. 